\title{
Aplikasi Pewarnaan Graf Peta Provinsi Riau Menggunakan Algoritma Greedy
}

\author{
Ade Novia Rahma ${ }^{1}$, Rahmawati ${ }^{2}$, Zukrianto $^{3 *}$ \\ ${ }^{1,2,3}$ UIN Sultan Syarif Kasim Riau \\ *zukrianto@yahoo.co.id
}

\begin{abstract}
ABSTRAK
Penelitian ini membahas tentang aplikasi pewarnaan graf pada peta Provinsi Riau menggunakan algoritma Greedy. Dalam aplikasi pewarnaan graf tersebut, terdapat beberapa langkah yang dikerjakan. Pertama mengubah gambar peta Provinsi Riau ke dalam bentuk graf. Kedua pewarnaan setiap kabupaten di Provinsi Riau menggunakan algoritma Greedy. Hasil akhirnya didapatkan pewarnaan graf di Provinsi Riau membutuhkan sebanyak empat warna yang berbeda.

Kata kunci: algoritma Greedy, pewarnaan wilayah, teori graf.
\end{abstract}

\section{ABSTRACT}

This study discusses the application of graphcoloring on maps of Riau Province using the Greedy algorithm. In the coloring graph application, there are several steps that are carried out. First, change the map image of Riau Province into graphic form. The second, colorizations for each district in Riau province use the Greedy algorithm. The final result is that graph coloring in Riau Province requires four different colors.

Keywords: Greedy algorithm, region coloring, graph theory. 


\section{PENDAHULUAN}

Teori graf merupakan topik yang banyak mendapat perhatian saat ini, karena modelmodel yang ada pada teori graf berguna untuk aplikasi yang luas. Walaupun teori graf berasal dari bidang ilmu Matematika, namun pada penerapannya, teori graf dapat dihubungkan dengan berbagai bidang ilmu dan juga kehidupan sehari-hari. Sedemikian banyaknya pengaplikasian graf dalam dunia ini, bila perlu dikatakan tidak ada habis-habisnya jika dibahas setiap aplikasi graf, karena setiap bidang ilmu dapat dikaitkan dengan graf seperti masalah dalam jaringan komunikasi, transportasi, ilmu komputer, riset operasi, ilmu kimia, sosiologi, kartografi dan lain sebagainya. Teori-teori mengenai graf ini telah banyak dikembangkan dengan berbagai algoritma yang memiliki kelebihan dan kelemahan masing-masing dalam menyelesaikannya. Graf adalah himpunan pasangan tak berurut antara simpul (vertices atau node) dan sisi (edges atau arcs).

Dalam kartografi, suatu peta dianggap baik dan benar jika mudah dimengerti oleh pembacanya yaitu jika dilengkapi dengan legenda, skala peta, judul peta, tata warna, simbol, dan proyeksi peta (Sandy, 1986). Salah satu manfaat tata warna peta yaitu memudahkan seseorang dalam mengenali beberapa negara yang berbatasan langsung. Dalam sebuah peta tergambar wilayah-wilayah yang dimiliki antar negara dan untuk membedakan wilayah antar negara tersebut, digunakan beberapa warna yang berbeda-beda. Jumlah warna yang berlebihan menyebabkan peta menjadi tidak efisien. Untuk itu diperlukan sebuah metode untuk melakukan pewarnaan peta menggunakan jumlah warna minimal.

Dalam teori graf, permasalahan dalam penentuan jumlah warna minimal yang bisa dibuat pada suatu representasi graf dikenal dengan bilangan kromatik (Wilson, 2004). Brun (2002) membahas banyak dalam kajiannya, salah satunya tentang Teorema Empat Warna yang menyatakan bahwa sebuah peta dapat diwarnai dengan menggunakan maksimal empat warna. Teori pewarnaan graf dapat diaplikasikan dalam penentuan warna pada sebuah peta yang dikenal sebagai pewarnaan wilayah. Ada beberapa penelitian terdahulu yang berkaitan secara tidak langsung dengan penelitian ini. Penelitian yang dilakukan oleh Hastuti (2011) membahas tentang pewarnaan Wilayah Peta Kabupaten Indragiri Hulu dan Kampar dengan Aplikasi Algoritma Greedy. Selanjutnya penelitian Mussafi (2015) masih membahas tentang Greedy Coloring Algorithm pada Peta Kotamadya Yogyakarta Berbasis Four-Colour Theorem. Kemudian Daswa \& Riyadi (2017) melakukan penelitian yang sedikit berbeda Pewarnaan Graf pada Masalah Penyusunan Jadwal Perkuliahan di Universitas Kuningan. Selanjutnya penelitian oleh Supiyandi \& Eka (2018) yang telah melakukan penelitian Penerapan Teknik Pewarnaan Graph Pada Penjadwalan Ujian dengan Algoritma Welch-Powell”. Kemudian pewarnaan graf juga dibahas oleh Bustan \& Salim (2019) Pewarnaan Graf Menggunakan Algoritma WelchPowell untuk Menentukan Jadwal Bimbingan Mahasiswa.

Penelitian dalam artikel ini sejalan dengan penelitian yang dilakukan Mussafi (2015) yaitu penggunaan Algoritma Greedy untuk menentukan bilangan kromatik suatu graf namun dengan objek penelitian yang berbeda. Tujuan dari penelitian ini adalah menerpkan Algoritma Greedy pada peta Provinsi Riau sehingga dapat diperoleh peta alternatif dengan pewarnaan minimal melalui analisis graf. 


\section{METODE}

\subsection{Landasan Teori}

Metode penelitian yang digunakan penulis yaitu dengan cara studi pustaka (literatur), yaitu dengan mempelajari buku-buku, jurnal atau artikel serta sumber-sumber yang berhubungan dengan penelitian ini.

Definisi 1 (Munir, 2014)

"Graf $G$ didefinisikan sebagai pasangan himpunan $(V, E)$ dinyatakan dengan notasi $G=(V, E)$. Dalam hal ini, $V$ adalah himpunan tidak kosong dari simpul (vertices dan node) dan $E$ adalah himpunan sisi (edges atau arcs) yang menghubungkan sepasang simpul."

\section{Definisi 2 (Munir, 2014)}

"Dua simpul dikatakan bertetangga apabila kedua simpul tersebut terhubung secara langsung oleh suatu sisi. Dengan kata lain, simpul $u$ bertetangga dengan $v$ jika $(u, v)$ adalah sebuah sisi pada graf $G . "$

\section{Definisi 3 (Munir, 2014)}

"Suatu sisi dikatakan bersisian dengan dua simpul apabila menghubungkan kedua simpul tersebut secara langsung."

\section{Definisi 4 (Munir, 2014)}

"Pada graf tidak berarah, derajat suatu simpul adalah banyaknya sisi yang bersisian dengan simpul tersebut. Sedangkan dalam graf berarah, derajat suatu simpul ( $v$ ) merupakan jumlah dari banyaknya busur yang masuk ke simpul (in) dengan banyaknya busur yang keluar dari simpul (out)."

\section{Definisi 5 (Munir, 2014)}

"Lintasan dari sebuah graf adalah barisan satu atau lebih sisi yang dilalui dari suatu simpul awal ke simpul tujuan. Panjang suatu lintasan adalah banyaknya sisi yang dilewati dari simpul awal ke simpul tujuan.”

\section{Definisi 6 (Munir, 2014)}

"Pewarnaan graf adalah pemberian warna yang biasanya direpresentasikan sebagai bilangan terurut mulai dari 1 hingga seterusnya atau dapat juga direpresentasikan langsung dengan menggunakan warna merah, biru, atau warna lainnya pada suatu graf. Objek tersebut dapat berupa simpul, sisi dan wilayah. Setiap simpul yang berdekatan atau bertetangga tidak mempunyai warna yang sama)."

Terdapat persoalan dalam pewarnaan graf, yaitu mewarnai graf tidak hanya sekedar memberikan warna pada simpul-simpul dengan warna yang berbeda dengan warna simpul tetangganya saja, namun dalam mewarnainya juga menginginkan jumlah jenis warna yang sedikit. 
Definisi 7 (Amrimirza, 2007)

Algoritma Greedy merupakan metode yang paling populer untuk memecahkan persoalan optimasi. Algoritma Greedy dalam pewarnaan graf adalah sebagai berikut.

1. Inisialisasi himpunan solusi dengan himpunan kosong.

2. Pemilihan simpul yang akan diisi warnanya dengan fungsi seleksi simpul.

3. Memilih kandidat warna dengan menggunakan fungsi seleksi warna. Kurangi warna pada kandidat $\mathrm{C}$ jika warna diambil dari himpunan kandidat $\mathrm{C}$.

4. Periksa kelayakan warna yang dipilih menggunakan fungsi kelayakan. Warna yang layak digunakan untuk simpul terpilih akan dimasukkan ke dalam himpunan solusi, jika tidak layak maka proses kembali ke langkah 2.

5. Periksa apakah solusi sudah meliputi pewarnaan seluruh simpul dengan solusi optimal menggunakan fungsi objektif. Proses pewarnaan akan berhenti jika pewarnaan telah mendapatkan solusi optimal, jika belum optimal kembali ke langkah 2.

\subsection{Metodologi Penelitian}

Penelitian ini bertujuan untuk mendapatkan pewarnaan graf minimum untuk peta wilayah Provinsi Riau dengan langkah-langkah sebagai berikut.

1. Menentukan batas-batas wilayah kabupaten untuk Provinsi Riau.

2. Mempresentasikan peta Provinsi Riau dalam graf dengan menjadikan batas-batas wilayah kabupaten sebagai sisi dan perpotongan antar batas wilayah sebagai simpul.

3. Mentukan derajat masing-masing simpul.

4. Melakukan pewarnaan peta Provinsi Riau menggunakan Algoritma Greedy.

5. Menentukan jumlah warna minimum yang diperoleh untuk mewarnai peta.

\section{HASIL DAN PEMBAHASAN}

\subsection{Representasi Graf Peta Wilayah Provinsi Riau}

Gambar 1 adalah gambar peta wilayah Provinsi Riau. Provinsi Riau terdiri dari 12 kabupaten yang memiliki batas-batas wilayahnya. Peta Provinsi Riau dapat direpresentasikan ke dalam sebuah graf dengan menjadikan batas-batas wilayah kabupaten sebagai sisi dan perpotongan antar batas wilayah sebagai simpul. Representasi daerah Provinsi Riau dalam suatu graf diperlihatkan pada Gambar 2.

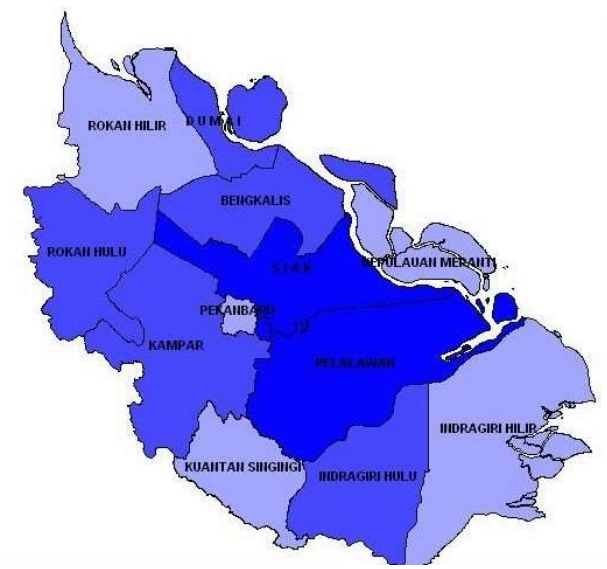

Gambar 1. Peta Provinsi Riau (Sumber: Google) 


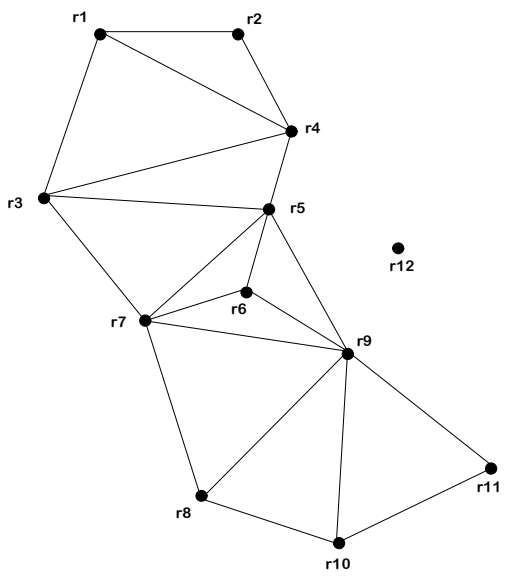

Gambar 2. Peta Provinsi Riau dalam Bentuk Graf

Pada Gambar 2, masing-masing titik merepresentasikan kabupaten-kabupaten yang berada di Provinsi Riau dengan keterangan sebagai berikut.

$\begin{array}{ll}\text { r1 } & \text { : Kabupaten Rokan Hilir } \\ \text { r2 } & \text { : Kabupaten Dumai } \\ \text { r3 } & \text { : Kabupaten Rokan Hulu } \\ \text { r4 } & \text { : Kabupaten Bengkalis } \\ \text { r5 } & \text { : Kabupaten Siak } \\ \text { r6 } & \text { : Kabupaten Pekanbaru }\end{array}$

r7 : Kabupaten Kampar

r8 : Kabupaten Kuantan Singgigi

r9 : Kabupaten Pelalawan

r10 : Kabupaten Indragiri Hulu

r11 : Kabupaten Indragiri Hilir

r12 : Kabupaten Kepulauan Meranti

Dari Gambar 2, dapat dibuat Tabel 1 yang meringkas banyaknya derajat pada masingmasing simpul.

Tabel 1. Derajat Simpul Graf Peta Provinsi Riau

\begin{tabular}{ccccccccccccc}
\hline Simpul & r1 & r2 & r3 & r4 & r5 & r6 & r7 & r8 & r9 & r10 & r11 & r12 \\
\hline Derajat & 3 & 2 & 4 & 4 & 5 & 3 & 5 & 3 & 6 & 3 & 2 & 0 \\
\hline
\end{tabular}

\subsection{Pewarnaan Peta Provinsi Riau Menggunakan Algoritma Greedy}

Pewarnaan peta Provinsi Riau dengan menggunakan Algoritma Greedy mengikuti langkah-langkah berikut.

1. Membangun Himpunan Kandidat $\mathrm{C}$

Himpunan kandidat $\mathrm{C}$ akan digunakan untuk mewarnai peta Provinsi Riau elemenelemen-nya terdiri dari 7 jenis warna, yakni $\mathrm{C}=\{$ Merah, Biru, Ungu, Kuning, Coklat, Hijau, Pink\}.

2. Inisialisasi Himpunan Solusi S

Inisialisasi himpunan solusi dengan kosong karena pada tahap selanjutnya nanti himpunan solusi akan memuat elemen warna yang telah digunakan untuk mewarnai simpul. Himpunan $\mathrm{S}=\{\}$. 
3. Mengurutkan Simpul

Berdasarkan Tabel 1, dapat dibentuk kembali Tabel 2 yang berisikan urutan berdasarkan jumlah derajat dari yang paling banyak hingga yang paling sedikit.

Tabel 2. Pengurutan Simpul Peta Provinsi Riau berdasarkan Jumlah Derajat Terbanyak

\begin{tabular}{ccccccccccccc}
\hline Simpul & r9 & r5 & r7 & r3 & r4 & r1 & r6 & r8 & r10 & r2 & r11 & r12 \\
\hline Derajat & 6 & 5 & 5 & 4 & 4 & 3 & 3 & 3 & 3 & 2 & 2 & 0 \\
\hline
\end{tabular}

4. Fungsi Seleksi

a. Fungsi Seleksi Simpul

Tahap seleksi simpul ini akan dipilih simpul awal yang akan di warnai terlebih dahulu. Simpul yang memiliki jumlah derajat terbanyak menjadi prioritas pengerjaan. Berdasarkan Tabel 2, simpul yang memiliki derajat terbanyak adalah simpul r9 maka dipilih simpul r9.

\section{b. Fungsi Seleksi Warna}

Tahap selanjutnya yaitu memilih warna yang akan digunakan untuk simpul r9, pada tahap seleksi warna dibagi kembali kedalam dua tahap. Tahap pertama adalah dengan mengambil warna dari himpunan solusi. Warna diuji apakah layak untuk digunakan kembali. Jika tidak satupun warna dari himpunan solusi layak atau himpunan solusi masih kosong, akan diambil warna dari himpunan kandidat $\mathrm{C}$ yang belum pernah digunakan.

Seleksi warna dari himpunan kandidat, warna yang akan digunakan simpul r9 ambil dari himpunan kandidat warna, dipilih warna merah yang merupakan kandidat warna pertama dari himpunan kandidat C. Selanjutnya, karena elemen kandidat warna pertama telah digunakan satu elemen maka elemen himpunan kandidat $\mathrm{C}$ tinggal 6 anggota yaitu $\mathrm{C}=\{$ Biru, Ungu, Kuning, Coklat, Hijau, Pink $\}$.

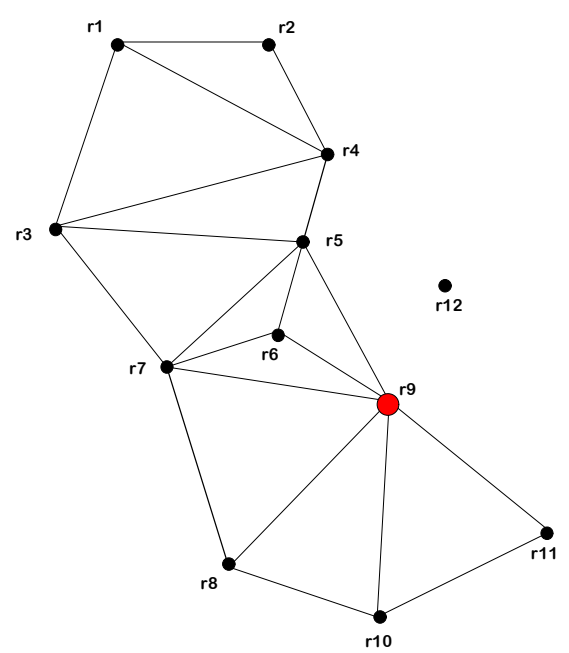

Gambar 3. Pewarnaan pada Simpul r9 
5. Fungsi Kelayakan

Akan diperiksa kelayakan warna merah yang digunakan untuk simpul r9, dapat dilihat dari matriks ketetanggaannya. Simpul r9 bertetangga dengan enam buah simpul yang belum diwarnai, sehingga warna merah layak digunakan untuk simpul r9.

6. Himpunan Solusi

Warna merah yang sudah digunakan untuk simpul $\mathrm{r} 9$ otomatis masuk ke dalam himpunan solusi. Himpunan solusi yang terbentuk yaitu $\mathrm{S}=\{$ Merah $\}$.

\section{Fungsi Objektif}

Tahap ini untuk memeriksa apakah solusi sudah meliputi pewarnaan seluruh simpul dengan solusi optimal, jika sudah maka berhenti dan jika belum kembali ke langkah seleksi simpul, karena pewarnaan simpul masih simpul r9, maka proses kembali ke langkah seleksi simpul.

8. Langkah Seleksi Simpul r5

Simpul yang akan diwarnai selanjutnya adalah simpul yang memiliki derajat paling banyak kedua yaitu simpul r5 dan simpul r7. Simpul yang dipilih simpul r5. Lalu diseleksi warna yang dianggap layak digunakan untuk simpul r5, ditahap sebelumnya warna merah diambil sebagai kandidat warna, sehingga pada tahap ini diambil kembali warna merah sebagai kandidat warna dengan diperiksa kelayakannya dengan melihat simpul tetangga dari simpul r5. Ternyata simpul r5 bertetangga dengan simpul r9 sehingga warna merah tidak layak sebagai himpunan solusi.

Selanjutnya dilakukan seleksi warna kembali dan kandidat warna diambil dari himpunan kandidat warna yang baru yaitu warna biru sehingga anggota himpunan kandidat warnanya sekarang adalah $\mathrm{C}=\{$ Ungu, Kuning, Coklat, Hijau, Pink $\}$. Setelah warna diambil maka akan diperiksa kembali kelayakannya. Simpul yang bertetangga dengan simpul r5 tidak berwarna biru sehingga biru layak digunakan pada simpul r5. Langkah selanjutnya adalah memasukkan warna biru ke himpunan solusi $\mathrm{S}=\{$ Merah, Biru $\}$.

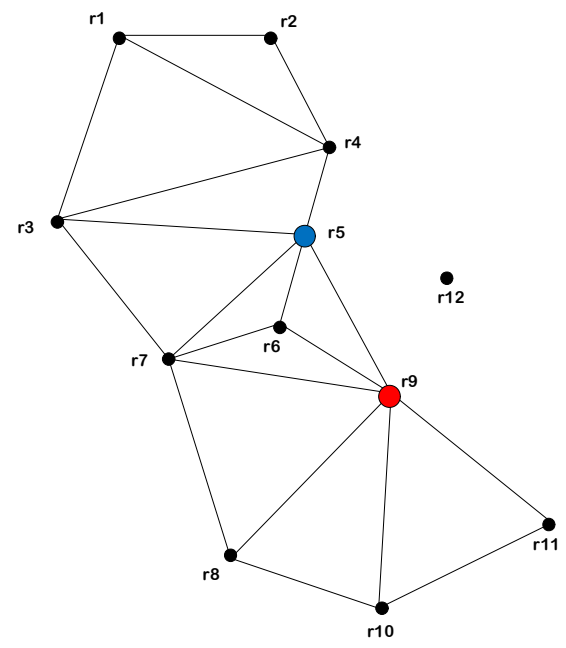

Gambar 4. Pewarnaan pada Simpul r5 
9. Langkah Seleksi Simpul r7

Selanjutnya akan dilakukan seleksi warna yang akan digunakan untuk simpul r7. Warna diambil dari himpunan solusi, dipilih elemen pertama dari himpunan solusi yaitu warna merah. Periksa kelayakan warna merah dengan melihat simpul tetangga dari simpul r7. Ternyata simpul r7 bertetangga dengan simpul r9 sehingga warna merah tidak layak sebagai himpunan solusi.

Selanjutnya pilih warna dari himpunan solusi dan dipilih warna kedua yaitu warna biru. Periksa kelayakan warna biru pada simpul r7. Ternyata simpul r7 bertetangga dengan simpul r5 sehingga warna biru juga tidak layak sebagai himpunan solusi.

Selanjutnya diambil warna baru dari himpunan kandidat warna yaitu warna ungu. Sehingga anggota himpunan kandidatnya sekarang menjadi $\mathrm{C}=\{$ Kuning, Coklat, Hijau, Pink\}. Setelah warna diambil maka akan diperiksa kembali kelayakannya, simpul yang bertetangga dengan simpul $r 7$ tidak berwarna ungu sehingga ungu layak digunakan pada simpul r7. Langkah selanjutnya adalah memasukkan warna ungu ke himpunan solusi sehingga $\mathrm{S}=\{$ Merah, Biru, Ungu $\}$.

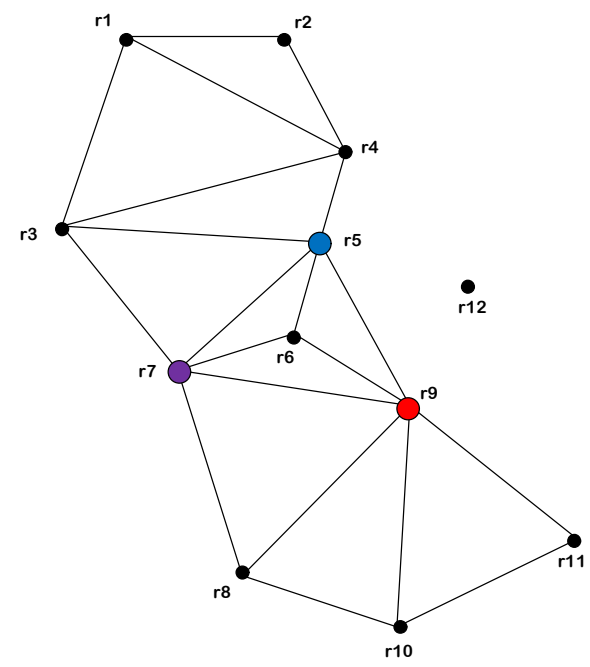

Gambar 5. Pewarnaan pada Simpul r7

\section{Langkah Seleksi Simpul r3}

Selanjutnya dilakukan seleksi warna yang akan digunakan untuk simpul r3. Warna diambil dari himpunan solusi, dipilih warna merah. Periksa kelayakan warna merah dengan melihat simpul tetangga dari simpul r3. Simpul r3 layak diwarnai menggunakan warna merah karena tidak ada simpul tetangganya memiliki warna yang sama. Langkah selanjutnya adalah memasukkan warna merah ke himpunan solusi sehingga $S=\{$ Merah, Biru, Ungu\} . 


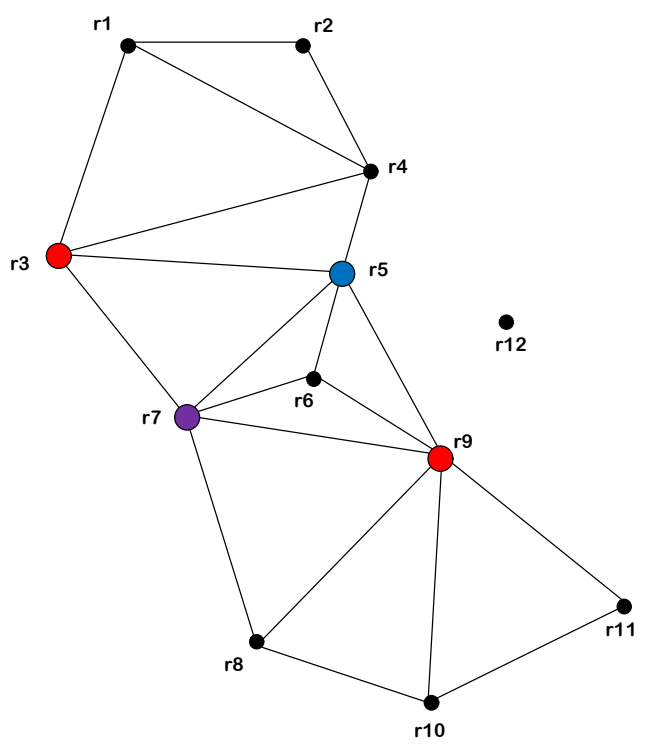

Gambar 6. Pewarnaan pada Simpul r3

\section{Langkah Seleksi Simpul r4}

Selanjutnya akan diseleksi warna yang dianggap layak digunakan untuk simpul r4. Diambil warna dari himpunan solusi, dipilih warna merah. Diperiksa kelayakan warna merah, simpul r4 bertetangga dengan simpul r3 yang berwarna merah sehingga warna merah tidak layak digunakan untuk simpul $\mathrm{r} 4$.

Selanjutnya diambil warna lain dari himpunan solusi yaitu warna biru. Simpul r5 yang bertetangga dengan simpul $\mathrm{r} 4$ sudah menggunakan warna biru sehingga warna biru tidak layak digunakan untuk simpul r4.

Selanjutnya diambil warna ungu dari himpunan solusi kemudian periksa kembali kelayakannya. Simpul yang bertetangga dengan simpul r4 tidak ada yang berwarna ungu sehingga warna ungu layak digunakan pada simpul r4. Langkah selanjutnya adalah memasukkan warna ungu ke himpunan solusi sehingga $S=\{$ Merah, Biru, Ungu $\}$.

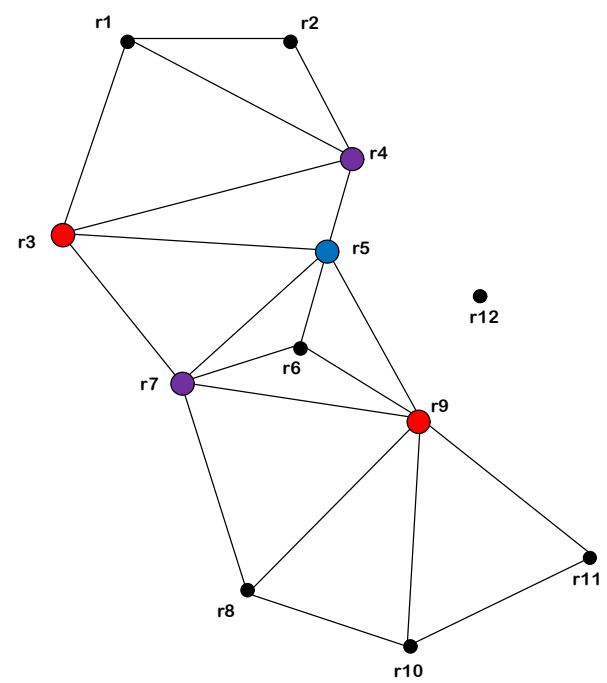

Gambar 7. Pewarnaan pada Simpul r4 
12. Langkah Seleksi Simpul r1

Selanjutnya akan diseleksi warna yang dianggap layak digunakan untuk simpul r1. Diambil warna dari himpunan solusi, dipilih warna merah. Diperiksa kelayakan warna merah, simpul $r 1$ bertetangga dengan simpul $r 3$ yang berwarna merah sehingga warna merah tidak layak digunakan untuk simpul r1.

Selanjutnya diambil warna biru dari himpunan solusi kemudian periksa kembali kelayakannya. Simpul yang bertetangga dengan simpul r1 tidak ada yang berwarna biru sehingga warna biru layak digunakan pada simpul r1. Langkah selanjutnya adalah memasukkan warna biru ke himpunan solusi sehingga $\mathrm{S}=\{$ Merah, Biru, Ungu $\}$.

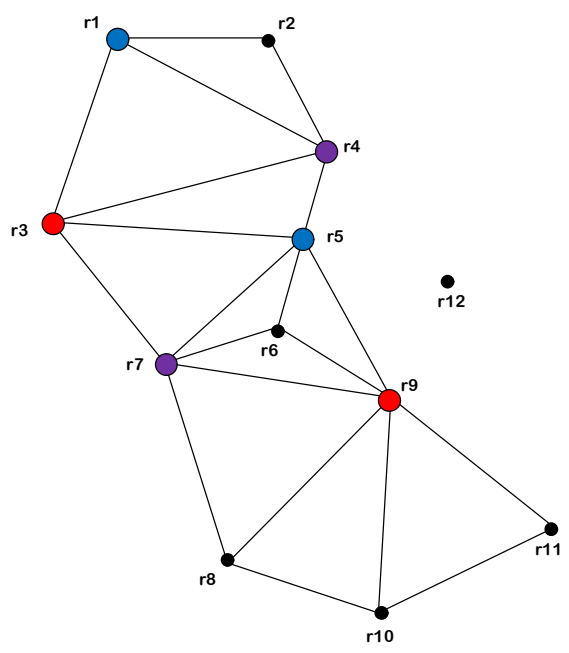

Gambar 8. Pewarnaan pada Simpul r1

\section{Langkah Seleksi Simpul r6}

Selanjutnya akan diseleksi warna yang dianggap layak digunakan untuk simpul r6. Diambil warna dari himpunan solusi, dipilih warna merah. Diperiksa kelayakan warna merah, simpul r6 bertetangga dengan simpul r9 yang berwarna merah sehingga warna merah tidak layak digunakan untuk simpul r6.

Selanjutnya diambil warna lain dari himpunan solusi yaitu warna biru. Simpul r5 yang bertetangga dengan simpul r6 sudah menggunakan warna biru sehingga warna biru tidak layak digunakan untuk simpul r6. Selanjutnya diambil warna lain dari himpunan solusi yaitu warna ungu. Simpul r7 yang bertetangga dengan simpul r6 sudah menggunakan warna ungu sehingga warna ungu juga tidak layak digunakan untuk simpul r6.

Selanjutnya diambil warna baru dari himpunan kandidat warna yaitu warna kuning. Sehingga anggota himpunan kandidatnya sekarang menjadi $\mathrm{C}=\{$ Coklat, Hijau, Pink $\}$. Setelah warna diambil maka akan diperiksa kembali kelayakannya, simpul yang bertetangga dengan simpul r6 tidak berwarna kuning sehingga kuning layak digunakan pada simpul r6. Langkah selanjutnya adalah memasukkan warna kuning ke himpunan solusi sehingga $\mathrm{S}=\{$ Merah, Biru, Ungu, Kuning $\}$. 


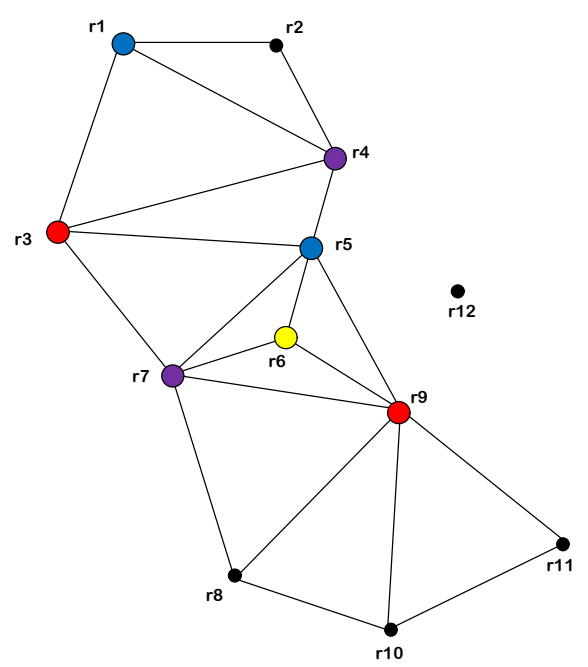

Gambar 9. Pewarnaan pada Simpul r6

14. Langkah Seleksi Simpul r8

Selanjutnya akan diseleksi warna yang dianggap layak digunakan untuk simpul r8. Diambil warna dari himpunan solusi, dipilih warna merah. Diperiksa kelayakan warna merah, simpul r8 bertetangga dengan simpul r9 yang berwarna merah sehingga warna merah tidak layak digunakan untuk simpul r8.

Selanjutnya diambil warna biru dari himpunan solusi kemudian periksa kembali kelayakannya. Simpul yang bertetangga dengan simpul r8 tidak ada yang berwarna biru sehingga warna biru layak digunakan pada simpul r8. Langkah selanjutnya adalah memasukkan warna biru ke himpunan solusi sehingga $S=\{$ Merah, Biru, Ungu, Kuning $\}$.

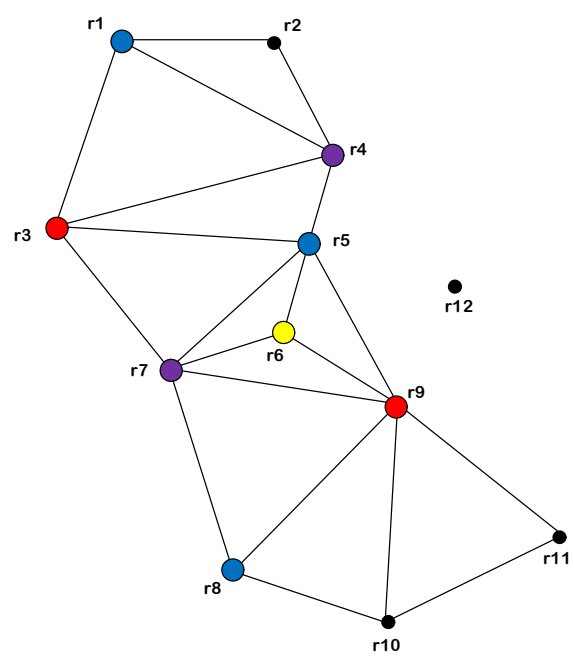

Gambar 10. Pewarnaan pada Simpul r8

15. Langkah Seleksi Simpul r10

Selanjutnya akan diseleksi warna yang dianggap layak digunakan untuk simpul r10. Diambil warna dari himpunan solusi, dipilih warna merah. Diperiksa kelayakan warna merah, simpul r10 bertetangga dengan simpul r9 yang berwarna merah sehingga warna 
merah tidak layak digunakan untuk simpul r10. Selanjutnya diambil warna lain dari himpunan solusi yaitu warna biru. Simpul r8 yang bertetangga dengan simpul r10 sudah menggunakan warna biru sehingga warna biru tidak layak digunakan untuk simpul r10.

Selanjutnya diambil warna ungu dari himpunan solusi kemudian periksa kembali kelayakannya. Simpul yang bertetangga dengan simpul r10 tidak ada yang berwarna ungu sehingga warna ungu layak digunakan pada simpul r10. Langkah selanjutnya adalah memasukkan warna ungu ke himpunan solusi sehingga $\mathrm{S}=$ \{Merah, Biru, Ungu, Kuning $\}$.

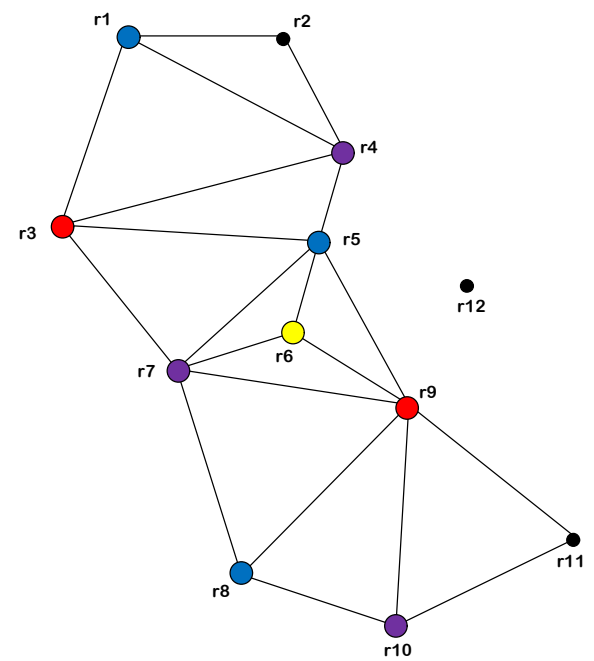

Gambar 11. Pewarnaan pada Simpul r10

16. Langkah Seleksi Simpul r2

Selanjutnya akan diseleksi warna yang dianggap layak digunakan untuk simpul r2. Diambil warna dari himpunan solusi, dipilih warna merah. Diperiksa kelayakan warna merah, simpul yang bertetangga dengan simpul $\mathrm{r} 2$ tidak ada yang berwarna merah sehingga warna merah layak digunakan pada simpul r2. Langkah selanjutnya adalah memasukkan warna merah ke himpunan solusi sehingga $S=\{$ Merah, Biru, Ungu, Kuning $\}$.

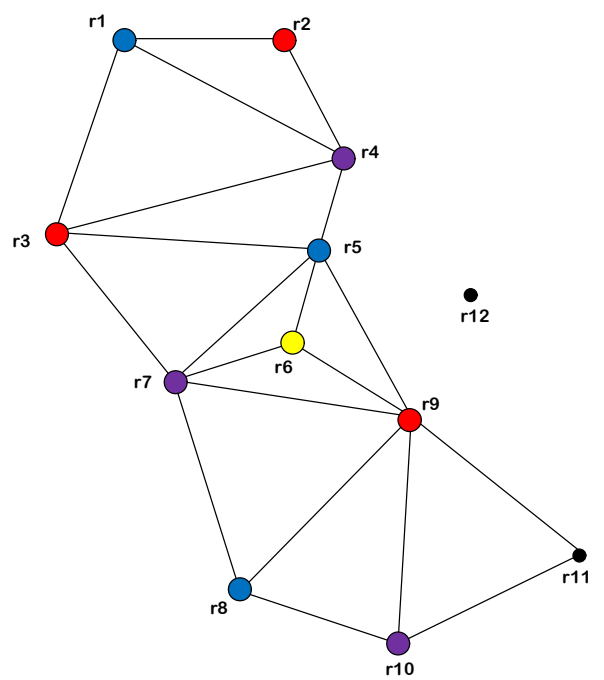

Gambar 12. Pewarnaan pada Simpul r2 
17. Langkah Seleksi Simpul r11

Selanjutnya akan diseleksi warna yang dianggap layak digunakan untuk simpul r11. Diambil warna dari himpunan solusi, dipilih warna merah. Diperiksa kelayakan warna merah, simpul r11 bertetangga dengan simpul r9 yang berwarna merah sehingga warna merah tidak layak digunakan untuk simpul r11.

Selanjutnya diambil warna lain dari himpunan solusi yaitu warna biru. Simpul yang bertetangga dengan simpul r11 tidak ada yang berwarna biru sehingga warna biru layak digunakan pada simpul r11. Langkah selanjutnya adalah memasukkan warna biru ke himpunan solusi sehingga $\mathrm{S}=\{$ Merah, Biru, Ungu, Kuning $\}$.

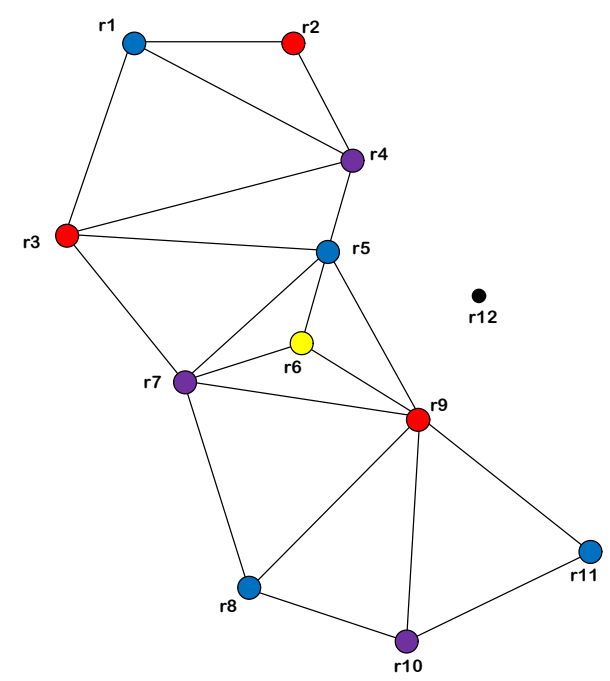

Gambar 13. Pewarnaan pada Simpul r11

18. Langkah Seleksi Simpul r12

Selanjutnya akan dilakukan seleksi warna yang akan digunakan untuk simpul r12. Warna diambil dari himpunan solusi, dipilih warna merah. Periksa kelayakan warna merah dengan melihat simpul tetangga dari simpul r12. Simpul r12 layak diwarnai menggunakan warna merah karena tidak memiliki simpul tetangganya. Langkah selanjutnya adalah memasukkan warna merah ke himpunan solusi sehingga $S=\{$ Merah, Biru, Ungu, Kuning $\}$.

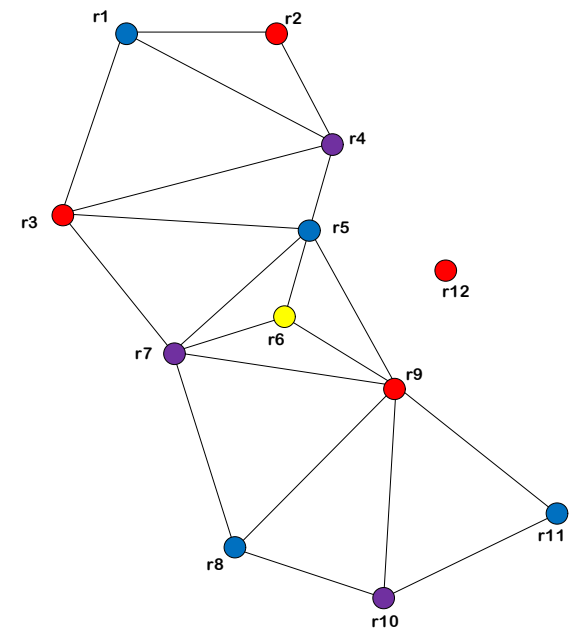

Gambar 14. Pewarnaan pada Simpul r12 
19. Fungsi Objektif

Karena seluruh simpul sudah diwarnai maka proses pewarnaan graf berhenti. Didapat himpunan solusi $\mathrm{S}=\{$ Merah, Biru, Ungu, Kuning $\}$.

\subsection{Menentukan Jumlah Warna Minimum Peta Provinsi Riau}

Jumlah warna minimum atau bilangan kromatik yang telah diperoleh setelah dilakukan pewarnaan graf menggunakan Algoritma Greedy pada peta Provinsi Riau dapat diwarnai menggunakan empat warna seperti pada Gambar 15.

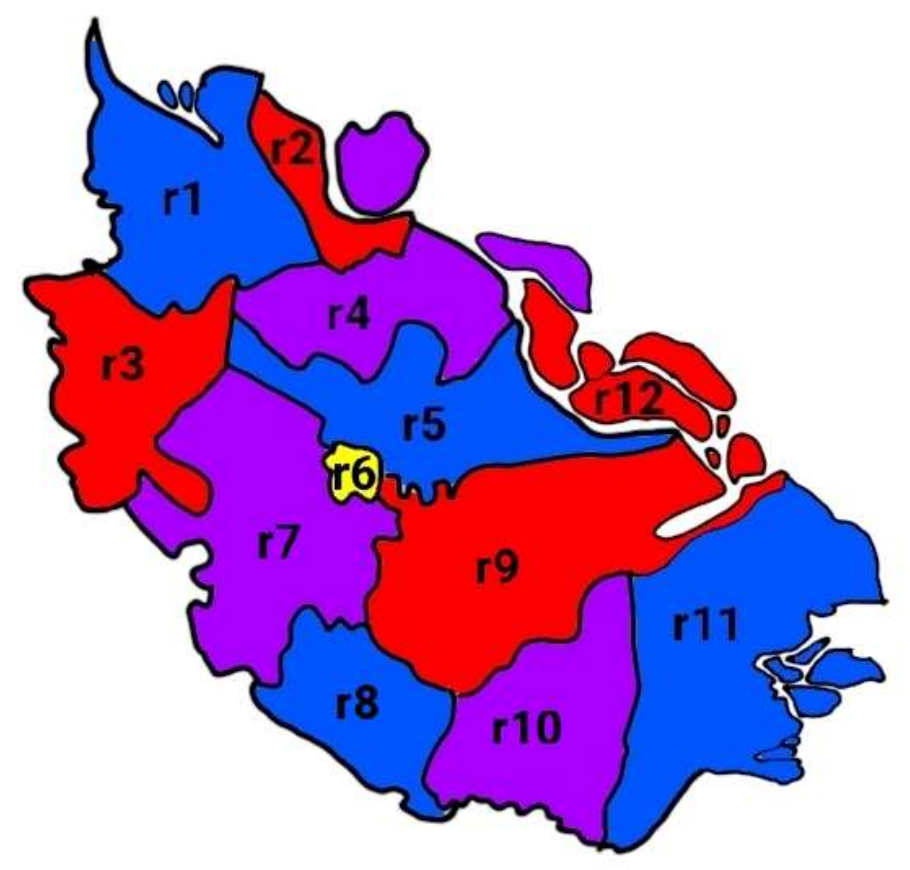

Gambar 15. Pewarnaan Wilayah Provinsi Riau

Keterangan:

r1 : Kabupaten Rokan Hilir

r2 : Kabupaten Dumai

r3 : Kabupaten Rokan Hulu

r4 : Kabupaten Bengkalis

r5 : Kabupaten Siak

r6 : Kabupaten Pekanbaru r7 : Kabupaten Kampar

r8 : Kabupaten Kuantan Singgigi

r9 : Kabupaten Pelalawan

r10 : Kabupaten Indragiri Hulu

r11 : Kabupaten Indragiri Hilir

r12 : Kabupaten Kepulauan Meranti

\section{SIMPULAN}

Dari hasil pembahasan yang telah dilakukan dapat disimpulkan bahwa pewarnaan peta Provinsi Riau dengan Algoritma Greedy diperoleh bilangan kromatik $\chi(G)=4$. Hal ini sesuai dengan pembahasan Brun (2002) tentang the four colour theorem yang menyatakan bahwa sebuah peta dapat diwarnai dengan maksimal empat warna. Dari hasil pewarnaan peta Provinsi Riau menggunakan Algoritma Greedy, diperoleh bahwa algoritma ini lebih rinci dan sistematis. Banyak langkah-langkah yang dilakukan pada Algoritma Greedy sehingga membutuhkan ketelitian yang lebih. 


\section{DAFTAR PUSTAKA}

Amrimirza, M. (2007) Aplikasi Algoritma Greedy pada Pewarnaan Peta, Makalah IF2251 Strategi Algoritmik. 1-4.

Brun, Yuriy. (2002). The Four-Color Theorem. Undergraduate Journal of Mathematics. 21-28.

Bustan, A. W., \& Salim, M. R. (2019). Penerapan Pewarnaan Graf Menggunakan Algoritma Welch-Powell Untuk Menentukan Jadwal Bimbingan Mahasiswa. Jurnal THEOREMS (The Original Research of Mathematics), 4(1), 79-86.

Daswa \& Riyadi, M. (2017). Aplikasi Pewarnaan Graf Pada Masalah Penyususnan Jadwal Perkuliahan Di Universitas Kuningan. JES-MAT, 3(2), 217-226.

Hastuti, W. F. (2011). Aplikasi algoritma Greedy untuk pewarnaan wilayah (region coloring) pada peta kabupaten indragiri hulu dan kampar di provinsi riau. Program Sarjana Universitas Islam Negeri Sultan Syarif Kasim Riau, Pekanbaru.

Munir, R. (2014). Matematika Diskrit Revisi Kelima. Bandung: Penerbit Informatika Bandung.

Mussafi, N. S. M. (2015). Penerapan Greedy Coloring Algorithm Pada Peta Kotamadya Yogyakarta Berbasis Four-Colour Theorem. Kaunia, vol. XI No. 1, April, 19-26.

Supiyandi \& Eka, M. (2018). Penerapan Teknik Pewarnaan Graph Pada Penjadwalan Ujian dengan Algoritma Welch-Powell. ALGORITMA: Jurnal Ilmu Komputer dan Informatika, 03(01), 58-63.

Rosen, K. H. (1999). Discrete Mathematics \& Applications. McGraw-Hill. 